\title{
Artemisia iwayomogi (Dowijigi) inhibits lipopolysaccharide-induced inflammation in RAW264.7 macrophages by suppressing the NF-кB signaling pathway
}

\author{
SEONG MIN KIM* ${ }^{*}$ PREETHI VETRIVEL ${ }^{*}$, HUN HWAN KIM, SANG EUN HA, \\ VENU VENKATARAME GOWDA SARALAMMA and GON SUP KIM \\ Research Institute of Life Science, College of Veterinary Medicine, Gyeongsang \\ National University, Jinju, Gyeongsang 52828, Republic of Korea
}

Received May 10, 2019; Accepted December 13, 2019

DOI: $10.3892 /$ etm.2020.8472

\begin{abstract}
Inflammatory diseases are an important health concern and have a growing incidence worldwide. Thus, developing novel and safe drugs to treat these disorders remains an important pursuit. Artemisia iwayomogi, locally known as Dowijigi (DJ), is a perennial herb found primarily in Korea and is used to treat various diseases such as hepatitis, inflammation and immune disorders. In the present study, the anti-inflammatory effects of a polyphenolic extract from the DJ flower (PDJ) in lipopolysaccharide (LPS)-stimulated mouse macrophage RAW264.7 cells were investigated. Cell cytotoxicity was assessed using the MTT assay. The production of nitric oxide (NO) and prostaglandin $\mathrm{E}_{2}\left(\mathrm{PGE}_{2}\right)$ was measured by Griess and ELISA analysis, respectively. The expression levels of inducible nitric oxide (iNOS) and cyclooxygenase-2 (COX2) were examined by western blot analysis. Reverse transcription-quantitative PCR was performed to detect the mRNA expression levels of pro-inflammatory cytokines, including tumor necrosis factor $\alpha$ (TNF $\alpha)$, interleukin (IL)-6 and IL-1 $\beta$, as well as COX2 and iNOS. The production of $\mathrm{NO}$ and $\mathrm{PGE}_{2}$ was significantly decreased following treatment with PDJ. The mRNA expression levels of TNF $\alpha$, IL-6, IL-1 $\beta$, COX2 and iNOS were significantly decreased in LPS-induced PDJ co-treated cells compared with the group treated with LPS alone. Western blot analysis indicated that PDJ downregulated the LPS-induced expression of iNOS and COX2, as well as the expression of $\mathrm{NF}-\kappa \mathrm{B}$
\end{abstract}

Correspondence to: Professor Gon Sup Kim, Research Institute of Life Science, College of Veterinary Medicine, Gyeongsang National University, 501 Jinju-daero, Jinju, Gyeongsang 52828, Republic of Korea

E-mail: gonskim@gnu.ac.kr

${ }^{*}$ Contributed equally

Key words: Dowijigi, anti-inflammation, inducible nitric oxide synthase, cyclooxygenase-2, NF- $\kappa \mathrm{B}$ signaling proteins. In conclusion, the present study demonstrated that PDJ exerted anti-inflammatory effects in LPS-induced macrophage cells by suppressing the $\mathrm{NF}-\kappa \mathrm{B}$ signaling pathway. Therefore, PDJ may be used as a potential therapeutic agent in inflammation.

\section{Introduction}

Inflammation is an important adaptive mechanism of the host immune response, and typically occurs at the site of infection. Inflammation is caused by cell injury and toxin exposure and is associated with a number of pathological conditions $(1,2)$. Inflammation plays a vital role in the body's defense system via multiple mediators that allow cells to recover from damage and to regulate tissue homeostasis $(3,4)$. Excessive and continuous inflammation can cause severe tissue damage that can lead to a series of disordered states, including hepatitis, pneumonia, atherosclerosis, septic shock and rheumatoid arthritis (5-7). The normal inflammatory response is self-limiting and is maintained by the downregulation of pro-inflammatory proteins and the upregulation of anti-inflammatory proteins (4). Therefore, targeting dysregulated inflammatory processes and regulating inflammatory mediators are regarded to be effective therapeutic approaches to managing inflammatory disorders $(8,9)$.

Lipopolysaccharide (LPS) is one of the most effective activators of macrophages (10). LPS induces the production of inflammatory cytokines and mediators such as tumor necrosis factor alpha (TNF- $\alpha$ ), interleukin-1 (IL-1), IL-2 and IL-18, resulting in the induction of inflammatory genes like TNF- $\alpha$, CXCL10, IL-2B and IL-10 via the activation of specific signaling cascades, at the transcription level $(4,11)$. The imbalance and build-up of oxidative stress in the cellular environment in disease conditions, including inflammation, stroke, cancer and diabetes, often increases the generation of reactive oxygen species (12-14). LPS-stimulated macrophages induce the production of large amounts of inflammatory mediators, including nitric oxide (NO) and prostaglandin $\mathrm{E}_{2}\left(\mathrm{PGE}_{2}\right)$. $\mathrm{NO}$ and $\mathrm{PGE}_{2}$ are secreted in inducible isoforms, iNOS and cyclooxygenase-2 (COX2), during the inflammatory response $(15,16)$. 
The nuclear transcription factor $\mathrm{NF}-\kappa \mathrm{B}$ is an important regulator that initiates inflammation (17). NF- $\kappa \mathrm{B}$ is activated by a series of intracellular signals involving inhibitor of $\kappa \mathrm{B}$ kinase (IKK) $\alpha / \beta$ proteins and its phosphorylation (18). The binding of LPS to the toll-like receptors (TLR) of activated macrophages leads to the phosphorylation and activation of IKK proteins, which allows the translocation of $N F-\kappa B$ into the cell nucleus, where pro-inflammatory cytokines are transcribed (19). A reduction in $\mathrm{NF}-\kappa \mathrm{B}$ signaling pathway activity and the expression of its related proteins have been shown to alleviate inflammatory responses (20). Thus, the $\mathrm{NF}-\kappa \mathrm{B}$ signaling pathway is a crucial target in the treatment of inflammatory diseases.

Artemisia iwayomogi, commonly known as Dowijigi (DJ), is a perennial herb that belongs to the composite asteraceae family, primarily found in Korea (21). A. iwayomogi exerts various biological effects such as anti-oxidation, anti-inhibition and anti-inflammation, and has been widely used in the treatment of various diseases, including hepatitis, inflammation, cholecystitis and immune-related disorders (22). Methanolic extracts of $A$. iwayomogi have been shown to exhibit scavenging activity in a number of diseases involving inflammation, and to inhibit NO production by LPS-activated macrophages (23). However, the mechanism underlying the anti-inflammatory effect of DJ remains largely unknown. The anti-inflammatory activities of the polyphenolic extract of Dowijigi (PDJ) can be assessed by measuring their potential to inhibit the production of inflammatory intermediates (24). Since macrophages play an important role in inflammation and immune defense responses, RAW264.7 mouse macrophage cells are one of the most commonly used cell line models to evaluate the anti-inflammatory effect of drugs in vitro (25). In the present study, the inhibitory effect of PDJ on inflammatory mediators in LPS-stimulated RAW264.7 cells and the underlying mechanism of action were investigated.

\section{Materials and methods}

Plant material. A. iwayomogi plants were collected in May 2018 from Namhae Island. The plant samples were authenticated under the Korea Animal Bioresource Research Bank (plant registration no. 00754C). The voucher specimens were deposited at the herbarium of the Research Institute of Life Science. The flowers were separated from the plants and were washed with water, lyophilized and stored at $-20^{\circ} \mathrm{C}$ prior to extraction.

Preparation of the PDJ. The lyophilized flowers were weighed $(100 \mathrm{~g})$ and refluxed in $70 \%$ methanol (2 liters) at $60^{\circ} \mathrm{C}$ for $20 \mathrm{~h}$. The extracted mixture was filtered through a Büchner funnel and concentrated to $\sim 300 \mathrm{ml}$ at $35^{\circ} \mathrm{C}$ at a variable pressure, using a rotary evaporator. To remove non-polar impurities from the concentrated filtrate, the filtrate was washed with n-hexane $(300 \mathrm{ml})$ three times. Furthermore, the filtrate was extracted using ethyl acetate $(100 \mathrm{ml})$ three times and dried over anhydrous magnesium sulfate. The solvent was removed from the rotatory evaporator. The resulting sticky residue was placed on the top of a silica gel sorbent $(40 \times 2.5 \mathrm{~cm})$ and eluted with ethyl acetate to eliminate highly polar impurities. The solvent was then removed to yield solids of polyphenol mixture (1.74 g; 1.74\% of the lyophilized plants). The mixture was stored at $-20^{\circ} \mathrm{C}$ until analysis.

High-performance liquid chromatography-tandem mass spectrometry (HPLC-MS/MS) analysis. HPLC analysis was conducted using a 1260 series HPLC system (Agilent Technologies, Inc.) with a multiple wavelength detector set at 254, 280, 320 or $360 \mathrm{~nm}$. A Prontosil C18 column (length, $250 \mathrm{~mm}$; inner diameter, $4.6 \mathrm{~mm}$; particle size, $5 \mu \mathrm{m}$; Phenomenex Co., Ltd.); Bischoff Chromatography) set at $30^{\circ} \mathrm{C}$ was used. The binary mobile phase system consisted of $0.1 \%$ formic acid in water (solvent $\mathrm{A}$ ) and $0.1 \%$ formic acid in acetonitrile (solvent $\mathrm{B}$ ). The gradient conditions were $0-10 \mathrm{~min}$ at $10 \% \mathrm{~B}, 10-60 \mathrm{~min}$ at $10-40 \% \mathrm{~B}, 60-70 \mathrm{~min}$ at $40-50 \% \mathrm{~B}$, $70-80 \mathrm{~min}$ at $50-10 \% \mathrm{~B}$ and $80-90 \mathrm{~min}$ at $10 \% \mathrm{~B}$. The flow rate was maintained at $1 \mathrm{ml} / \mathrm{min}$ and a sample injection volume of $10 \mu \mathrm{l}$ was used in each experiment. The electrospray ionization MS/MS analysis was conducted using a 3200 QTrap LC/MS/MS system (Applied Biosystems, Fortser, CA, USA) operated in negative ion mode (spray voltage set at $-4.5 \mathrm{kV}$ ) and nitrogen at a pressure of 45 psi was used as nebulizing agent and drying gas was supplied. The mass spectra were recorded in the range of $\mathrm{m} / \mathrm{z} 100-1000$. The obtained data were analyzed using BioAnalystTM software (version 1.4.2; SCIEX).

Cell culture. Mouse RAW264.7 macrophage cells were obtained from the American Type Culture Collection and cultured in complete DMEM (Gibco; Thermo Fisher Scientific, Inc.) containing 10\% heat-inactivated fetal bovine serum (FBS; Gibco; Thermo Fisher Scientific, Inc.) and supplemented with $100 \mathrm{U} / \mathrm{ml}$ penicillin and $100 \mu \mathrm{g} / \mathrm{ml}$ streptomycin (Thermo Fisher Scientific, Inc.). The cells were incubated at $37^{\circ} \mathrm{C}$ in a humidified atmosphere containing $5 \% \mathrm{CO}_{2}$.

Cell viability assay. RAW264.7 cells were seeded at a density of $1 \times 10^{4}$ cells per well in 96 well plate and then cultured with or without LPS ( $1 \mu \mathrm{g} / \mathrm{ml}$; Sigma-Aldrich; Merck KGaA) pre-treatment at $37^{\circ} \mathrm{C}$ for $1 \mathrm{~h}$, followed by treatment with various concentration of PDJ $(0.5,1,2.5,5$ and $10 \mu \mathrm{g} / \mathrm{ml})$ at $37^{\circ} \mathrm{C}$ for $24 \mathrm{~h}$. After incubation, MTT solution $(10 \mu \mathrm{l} ; 5 \mathrm{mg} / \mathrm{ml})$ was added to the plate and the cells were incubated at $37^{\circ} \mathrm{C}$ for $\sim 4 \mathrm{~h}$. Then, the culture media was washed off completely and the insoluble formazan crystals formed were dissolved in DMSO. The absorbance was measured at a wavelength of $590 \mathrm{~nm}$ using a PowerWave HT microplate spectrophotometer (BioTek Instruments, Inc.).

Griess assay for NO detection. NO production in the cell cultures was measured using the Promega Griess Reagent system (Promega Corporation) according to the manufacturer's instructions. Briefly, RAW264.7 cells were cultured at a density of $1 \times 10^{4}$ cells per well in 96 -well plates with or without LPS pre-treatment at $37^{\circ} \mathrm{C}$ for $1 \mathrm{~h}$. Subsequently, cells were treated with either 2.5 or $5 \mu \mathrm{g} / \mathrm{ml}$ PDJ and incubated at $37^{\circ} \mathrm{C}$ for $24 \mathrm{~h}$. After incubation, the media in each group was collected and mixed with $50 \mu \mathrm{l}$ sulfanilamide solution and $50 \mu \mathrm{l}$ Griess reagent for $10 \mathrm{~min}$ at room temperature, protected from light. The nitrate concentration was measured at a wavelength of $520 \mathrm{~nm}$. Sodium nitrite was used to generate the 
standard curve and NO production in the culture medium was estimated from the $\mathrm{NO}_{2}$ concentration.

ELISA. RAW264.7 cells were seeded at a density of $5 \times 10^{4}$ per well in 48 -well plates. The cells were pre-treated with $1 \mu \mathrm{g} / \mathrm{ml}$ LPS at $37^{\circ} \mathrm{C}$ for $1 \mathrm{~h}$ and then incubated with 2.5 or $5 \mu \mathrm{g} / \mathrm{ml}$ of PDJ for $24 \mathrm{~h}$ at $37^{\circ} \mathrm{C}$. Levels of IL-1 $\beta$, IL- 6 and TNF $\alpha$ were quantified using the mouse IL-1 $\beta$ (cat. no. ADI-900-132A; Enzo Life Sciences, Inc.), IL-6 (cat. no. ADI-900-045; Enzo Life Sciences, Inc.) and TNFa (cat. no. ADI-900-047; Enzo Life Sciences, Inc.) ELISA kits, respectively, according to the manufacturer's instructions.

ELISA for measuring PGE $E_{2}$ levels. $\mathrm{PGE}_{2}$ levels in the cells were analyzed using a $\mathrm{PGE}_{2}$ assay kit (cat. no. ADI-900-001; Enzo Life Sciences, Inc.), according to manufacturer's protocol. RAW264.7 cells were cultured at a density of $1 \times 10^{4}$ cells per well in 96-well plates with or without LPS pre-treatment at $37^{\circ} \mathrm{C}$ for $1 \mathrm{~h}$. Cells were subsequently treated with either 2.5 or $5 \mu \mathrm{g} / \mathrm{ml}$ PDJ and incubated at $37^{\circ} \mathrm{C}$ for $24 \mathrm{~h}$. After PDJ treatment, $100 \mu \mathrm{l}$ standard diluent was added to the ELISA plate, followed by $100 \mu \mathrm{l}$ sample and $\sim 50 \mu \mathrm{l}$ assay buffer. Then, $50 \mu 1 \mathrm{PGE}_{2}$ conjugate was added to the plate, followed by $50 \mu 1 \mathrm{PGE}_{2}$ antibody. No antibody was added to the blank wells. The plates were incubated for $2 \mathrm{~h}$ on a shaker at room temperature. After $2 \mathrm{~h}$, the contents of the wells were emptied and the wells were washed three times with $400 \mu 1$ of $1 \mathrm{X}$ wash solution from the $\mathrm{PGE}_{2}$ assay kit. After the final wash, media were aspirated from the wells and $5 \mu$ l conjugate solution was added. Subsequently, $200 \mu 1$ p-nitrophenyl phosphate substrate solution was added to the wells followed by incubation at room temperature for $\sim 45 \mathrm{~min}$ without shaking. The reaction was stopped by the addition of $50 \mu \mathrm{l}$ stop solution to the wells and the absorbance was measured at a wavelength of $405 \mathrm{~nm}$.

Determination of protein expression by western blot analysis. For western blot analysis, RAW264.7 cells were seeded into 6 -well plates at a density of $6 \times 10^{5}$ cells/well and treated with 2.5 or $5 \mu \mathrm{g} / \mathrm{ml}$ PDJ for $24 \mathrm{~h}$ at $37^{\circ} \mathrm{C}$. Then, the cells were lysed in ice-cold RIPA buffer [50 mM Tris- $\mathrm{HCl}(\mathrm{pH} \mathrm{8.0)}$, $0.5 \%$ sodium deoxycholate, $1 \mathrm{mM}$ EDTA, $150 \mathrm{mM} \mathrm{NaCl}$, 0.1 SDS and 1\% NP-40]. Protein concentrations were determined using the Pierce ${ }^{\mathrm{TM}}$ bicinchoninic acid protein assay kit (Thermo Fisher Scientific, Inc.), according to the manufacturer's instructions. Equal amounts of protein $(\sim 10 \mu \mathrm{g})$ were separated on via SDS-PAGE on $10 \%$ gels and transferred onto PVDF membranes using the TE 77 Semi-Dry Transfer Unit (GE Healthcare Life Sciences). The blots were then blocked with $5 \%$ skimmed milk and 5\% bovine serum albumin (BSA; Thermo Fisher Scientific, Inc.) for $1 \mathrm{~h}$ at room temperature. Membranes were further incubated with 1:1,000 dilutions of primary antibodies overnight at $4^{\circ} \mathrm{C}$. Primary antibodies of COX-2 (cat. no. 12282S; 1:1,000), iNOS (cat. no. 13120S; 1:1,000), p65 (cat. no. 8242S; 1:1,000), p-p65 (cat. no. Ser536; $3033 \mathrm{~S} ; 1: 1,000), \mathrm{I} \kappa \mathrm{B} \alpha$ (cat. no. $4812 \mathrm{~S} ; 1: 1,000)$, p-ІкB $\alpha$ (Ser32; cat. no. 2859S; 1:1,000), JNK (cat. no. 9258S, 1:1,000), p-JNK1/2 (Thr183/Tyr185; cat. no. 4671S, 1:1,000), p38 (cat. no. 8690S; 1:1,000), p-p38 (Thr180/Tyr182; cat. no. 9216S, 1:1,000), ERK1/2 (cat. no. 4695S; $1: 1,000)$, p-ERK1/2 (Thr202/Tyr204; cat. no. 4970S, 1:1,000), and $\beta$-actin (cat. no. 3700S, 1:10,000) were purchased from Cell Signaling Technology, Inc. The membranes were washed three times for 10 min with TBST and then probed with the appropriate horseradish peroxidase-conjugated secondary antibody (anti-rabbit and anti-mouse, A120-101P and A90-116P, respectively, Bethyl Laboratory, Inc.) for $3 \mathrm{~h}$ at room temperature. The blots were visualized using Clarity ${ }^{\mathrm{TM}}$ ECL substrate reagent (Bio-Rad Laboratories, Inc.) and quantified by densitometry using ImageJ software (National Institutes of Health) with $\beta$-actin as the loading control. The experiment was performed in triplicate.

Determination of $m R N A$ expression by reverse transcription-quantitative PCR (RT-qPCR). To determine the mRNA expression levels of related proteins, RAW264.7 cells were seeded into 6-well plates at a density of $5 \times 10^{5}$ cells/well and treated with LPS at $37^{\circ} \mathrm{C}$ for $1 \mathrm{~h}$, followed by co-treatment with 2.5 or $5 \mu \mathrm{g} / \mathrm{ml} \mathrm{PDJ}$ for $24 \mathrm{~h}$ at $37^{\circ} \mathrm{C}$. The total RNA content was isolated using Trizol ${ }^{\circledR}$ reagent (Thermo Fisher Scientific, Inc.) and the concentration of RNA was measured using a spectrophotometer. Total RNA $(1 \mu \mathrm{g})$ was converted to cDNA using the iScript ${ }^{\mathrm{TM}}$ cDNA synthesis kit (Bio-Rad Laboratories, Inc.) and qPCR was performed with AccuPower ${ }^{\circledR} 2 \mathrm{X}$ Greenstar ${ }^{\mathrm{TM}}$ qPCR Mastermix (Bioneer Corporation) and a CFX384 Real Time PCR Detection system (Bio-Rad Laboratories, Inc.) according to each manufacturer's protocol, respectively. The qPCR primers used were as follows: TNF $\alpha$ sense, 5'-TGG AGTCATTGCTCTGTGAAGGGA-3' and antisense, 5'-AGT CCTTGATGGTGGTGCATGAGA-3'; IL-6 sense, 5'-GAG GATACCACTCCCAACAGACC-3' and antisense, 5'-AAG TGCATCATCGTTGTTCATACA-3'; IL-1 $\beta$ sense, 5'-TGC AGAGTTCCCCAACTGGTACATC-3' and antisense, 5'-GTG CTGCCTAATGTCCCCTTGAATC-3'; iNOS sense, 5'-TCC TACACCACACCAAAC-3' and antisense, 5'-CTCCAATCT CTGCCTATC-3'; COX2 sense, 5'-CCTCTGCGATGCTCT TCC-3' and antisense, 5'-TCACACTTATACTGGTCAAAT CC-3'; and $\beta$-actin sense, 5'-TACTGCCCTGGCTCCTAGCA-3' and antisense, 5'-TGGACAGTGAGGCCAGGATAG-3'. The thermocycling conditions were as follows: Pre-denaturation for $2 \mathrm{~min}$ at $95^{\circ} \mathrm{C}$, followed by 40 cycles at $95^{\circ} \mathrm{C}$ for $5 \mathrm{sec}, 58^{\circ} \mathrm{C}$ for $30 \mathrm{sec}$ and $95^{\circ} \mathrm{C}$ for $5 \mathrm{sec}$. All the data were analyzed using Bio-Rad CFX Manager Version 3.1 software. Relative quantification was measured using the $2^{-\Delta \Delta \mathrm{Cq}}$ method (26). The mRNA expression levels were normalized against $\beta$-actin.

Statistical analysis. The data are expressed as the mean \pm SEM. Data were analyzed using GraphPad Prism software (version 5.02; GraphPad Software, Inc.). Statistically significant differences were calculated using one-way ANOVA followed by Bonferroni's post hoc test. $\mathrm{P}<0.05$ was considered to indicate a statistically significant difference.

\section{Results}

Separation and quantification of PDJ. PDJ was separated and quantified using HPLC-MS/MS. A total of 37 peaks were identified based on the HPLC retention times and the UV-vis spectra (Fig. 1). The phenolic compounds and flavonoids were identified according to the peaks obtained in the HPLC chromatogram and the description of their mass spectrometry 


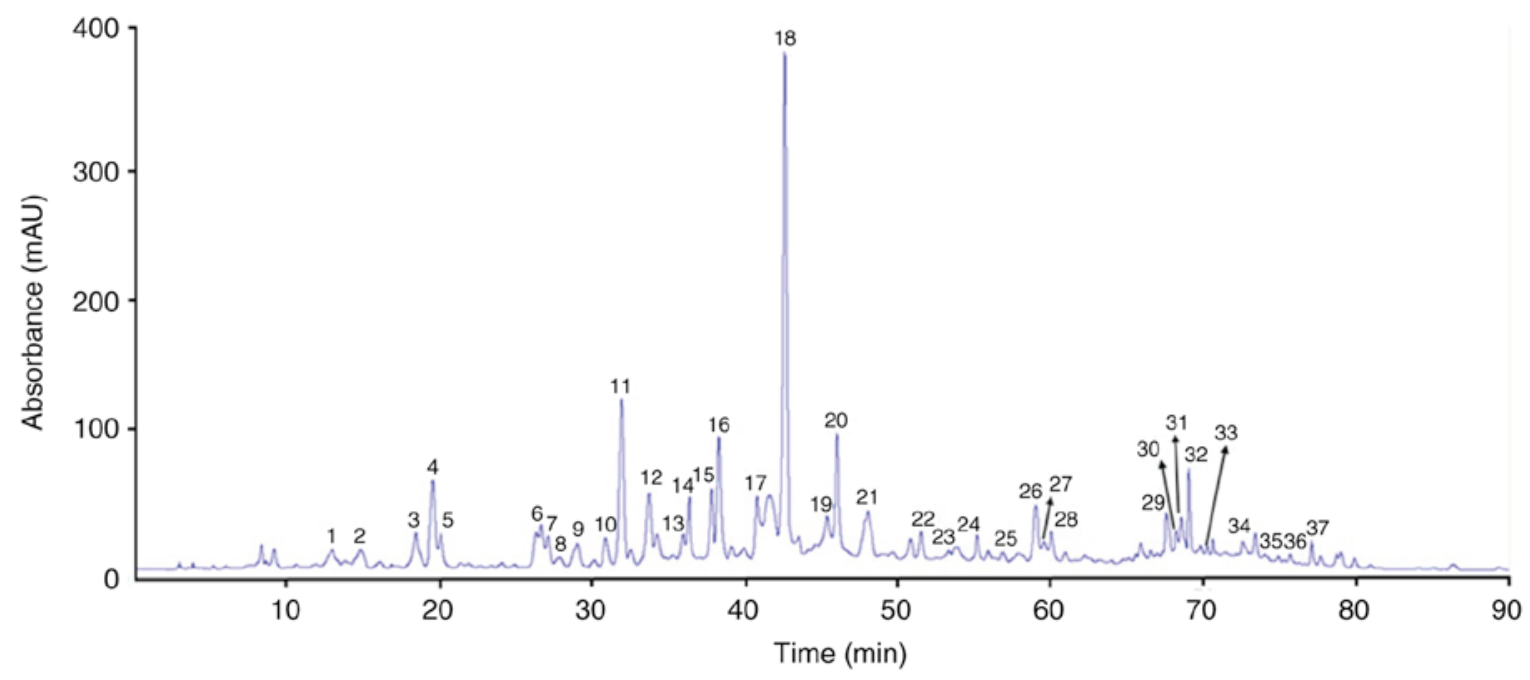

Figure 1. High-performance liquid chromatography chromatogram of polyphenols obtained from the flower extract of Artemeisa iwayonogi (Dowijigi).

quantification data based on the reference compounds from published sources are provided in Table I.

Cytotoxic effect of PDJ in RAW264.7 cells. To identify the non-toxic dose of PDJ, cells were treated with increasing concentrations of PDJ $(0,0.5,1,2.5,5$ and $10 \mu \mathrm{g} / \mathrm{ml})$ following pre-treatment with or without LPS for $1 \mathrm{~h}$. The results suggested that concentrations of PDJ $\leq 10 \mu \mathrm{g} / \mathrm{ml}$ were non-toxic, therefore, doses of 2.5 and $5 \mu \mathrm{g} / \mathrm{ml}$ were used for subsequent experiments (Fig. 2A and B).

PDJ inhibits LPS-induced NO production and $P G E_{2}$. The effect of PDJ on NO production in LPS-induced RAW264.7 cells was measured by the Griess assay. Cells were pre-treated with LPS $(1 \mu \mathrm{g} / \mathrm{ml})$ for $1 \mathrm{~h}$ followed by treatment with PDJ $(2.5$ or $5 \mu \mathrm{g} / \mathrm{ml})$. Treatment with LPS induced a significant $(\mathrm{P}<0.001)$ increase in NO production, which was suppressed upon further treatment with PDJ at both concentrations (Fig. 3A). Thus, there was a decrease in the NO accumulation in the cells co-treated with PDJ and LPS compared with those treated with LPS alone. The level of $\mathrm{PGE}_{2}$ in the LPS-induced RAW264.7 cells treated with PDJ was measured using a $\mathrm{PGE}_{2}$ ELISA kit. The intensity of the bound antibody was measured to calculate the concentration of $\mathrm{PGE}_{2}$ in the PDJ-treated cells. The results displayed that $\mathrm{PGE}_{2}$ levels significantly $(\mathrm{P}<0.001)$ decreased upon treatment with PDJ compared with LPS-only treated cells (Fig. 3B).

PDJ inhibits LPS-induced $m R N A$ and protein expression of iNOS and COX2. The effect of PDJ on COX 2 and iNOS mRNA and protein expression levels in LPS-induced RAW264.7 cells was evaluated by RT-qPCR analysis and western blotting, respectively. The expression of COX2 and iNOS in RAW264.7 cells stimulated with LPS was significantly $(\mathrm{P}<0.001)$ increased compared with the non-LPS treated control cells, at both the protein (Fig. 4A and B) and mRNA (Fig. 5A and B) level. However, the protein and mRNA expression levels of COX2 and iNOS in the RAW264.7 cells were significantly $(\mathrm{P}<0.001)$ decreased after treatment with PDJ. The results indicated that PDJ downregulated
LPS-induced COX2 and iNOS expression at both the mRNA and protein levels.

PDJ inhibits LPS-induced mRNA expression of the inflammatory cytokines $T N F \alpha, I L-6$ and $I L-1 \beta$. The effect of PDJ on the mRNA expression levels of inflammatory cytokines IL-6, IL-1 $\beta$ and TNF $\alpha$ in LPS-induced RAW264.7 cells was evaluated by RT-qPCR. mRNA levels of the inflammatory cytokines were significantly increased $(\mathrm{P}<0.001)$ following LPS treatment compared with the untreated control group. The levels of IL-6, IL-1 $\beta$ and TNF $\alpha$ expression decreased in LPS-treated RAW264.7 cells that were also treated with PDJ (Fig. 6A-C). The results indicated that PDJ suppressed cytokine expression at the transcriptional level in LPS-induced RAW264.7 cells.

PDJ induces anti-inflammatory effects in LPS-stimulated $R A W 264.7$ cells via regulation of the $N F-\kappa B$ signaling pathway. The effect of PDJ on the LPS-induced degradation and phosphorylation of $\mathrm{NF}-\kappa \mathrm{B}$ proteins and the expression levels of inhibitor of $\kappa \mathrm{B} \alpha(\mathrm{I} \kappa \mathrm{B} \alpha)$ and p65 were analyzed by western blotting. The results indicated that PDJ treatment following LPS-stimulation decreased $\mathrm{p}-\mathrm{I} \kappa \mathrm{B} \alpha$ and $\mathrm{p}-\mathrm{p} 65$ protein expression, whereas the expression of p65 and I $\mathrm{B} \alpha$ remained unchanged (Fig. 7). The results suggested that PDJ increased $\mathrm{I} \kappa \mathrm{B} \alpha$ and p 65 protein levels by dephosphorylating $\mathrm{I} \kappa \mathrm{B} \alpha$ and $\mathrm{p} 65$ in LPS-induced RAW264.7 cells.

\section{Discussion}

Plant extracts are attracting greater interest in anti-inflammatory drug discovery due to their low side effect profile and effective mode of action (27). Numerous varieties of phytoconstituents present in plants, including phenols, flavonoids and alkaloids, are responsible for the effective biological activities of plants, including antioxidant, anti-inflammatory, anti-atherosclerotic, anti-tumor, anti-bacterial and anti-viral effects (28). Compounds isolated from DJ exert pharmacological effects in a number of diseases and processes, including obesity, diabetes, fatty liver, inflammation and aging $(23,29,30)$. However, to the best of our knowledge, no 
Table I. MS/MS data of the polyphenols in Artemisia iwayonogi (Dowijigi).

\begin{tabular}{|c|c|c|c|c|c|c|}
\hline Peak no. & Compound & $\begin{array}{l}\text { Retention } \\
\text { time }(\min )\end{array}$ & $\begin{array}{c}\text { UV } \\
\max , \mathrm{nm}\end{array}$ & {$[\mathrm{M}-\mathrm{H}]^{-}$} & $\mathrm{MS} / \mathrm{MS}$ & (Refs.) \\
\hline 1 & Protocatechuic aldehyde & 12.866 & 278,310 & 137 & 109 & $(40)$ \\
\hline 2 & Gallocatechin & 14.713 & 272 & 305 & $261,221,219,179$ & (41) \\
\hline 3 & Methyl catechin & 18.337 & 272 & 305 & 137 & (42) \\
\hline 4 & Epicatechin & 19.460 & 272 & 305 & 139 & $(42)$ \\
\hline 5 & Caffeic acid & 19.979 & 323 & 179 & 135 & $(43)$ \\
\hline 6 & Epigallocatechin & 26.570 & 272 & 305 & $261,221,219,179$ & (41) \\
\hline 7 & Catechin & 27.003 & 272 & 289 & 245,205 & (41) \\
\hline 8 & 5-caffeoylquinic acid & 27.718 & 284 & 353 & 191 & $(41)$ \\
\hline 9 & Epigallocatechin-3-gallate & 28.929 & 294 & 457 & $331,305,169$ & (41) \\
\hline 10 & 5-Feruoylquinic acid & 30.802 & 272 & 367 & $193,191,173$ & $(44)$ \\
\hline 11 & Rhamnose-C-acetyl-hexoside apigenin & 31.828 & 344 & 619 & $\begin{array}{l}499,457,413,341, \\
311,293,315\end{array}$ & $(45)$ \\
\hline 12 & Liquiritigenin-7-O-sulfate & 33.610 & 342 & 335 & $255,135,119$ & $(46)$ \\
\hline 13 & Quercetin-rutinoside & 35.853 & 254,352 & 609 & 301 & $(41)$ \\
\hline 14 & Quercetin-3-galactoside & 36.234 & 254,370 & 463 & 301 & $(47)$ \\
\hline 15 & Quercetin-3-glucoside & 37.718 & 256,354 & 463 & 301 & $(47)$ \\
\hline 16 & Malyidin-3-glucoside & 38.211 & 256,354 & 493 & 331 & $(48)$ \\
\hline 17 & 3,4-di-O-Caffeoylquinic acid & 40.702 & 326,300 & 515 & $353,335,191,179,173$ & (49) \\
\hline 18 & 3,5-di-O-Caffeoylquinic acid & 42.525 & 328,300 & 515 & $353,354,191,179$ & $(9)$ \\
\hline 19 & Quinic acid derivate & 45.298 & 324,226 & 515 & $353,335,191,179,173$ & $(50)$ \\
\hline 20 & 4,5-di-O-Caffeoylquinic acid & 45.929 & 326,300 & 515 & $\begin{array}{l}353,335,317,299 \\
191,179,173\end{array}$ & $(49)$ \\
\hline 21 & Mearnsetin-O-diglucoside & 47.971 & 330 & 655 & $\begin{array}{l}535,493,492,331 \\
329,316,301\end{array}$ & $(50)$ \\
\hline 22 & Quercetin diglycoside & 51.437 & 330 & 771 & $609,463,608,301,300$ & $(49)$ \\
\hline 23 & Quercetin dihexoside & 53.260 & 354 & 625 & 463,301 & $(45)$ \\
\hline 24 & Caffeoyl dihexoside & 53.816 & 328 & 503 & $342,341,179$ & $(49)$ \\
\hline 25 & 3-Caffeoyl-4-feruoyl-quinic acid & 56.817 & 322,286 & 529 & $\begin{array}{l}367,353,255,203, \\
191,179,173\end{array}$ & $(50)$ \\
\hline 26 & Luteolin & 58.962 & 358,254 & 285 & 133 & $(51)$ \\
\hline 27 & Isorhamnetin & 59.497 & 344,268 & 315 & 300 & $(51)$ \\
\hline 28 & 5,7,4',5'-Tetrahydroxy-6,3'-Dimethoxyflavone & 59.991 & 348,270 & 345 & $330,315,287,259,136$ & $(44)$ \\
\hline 29 & Mearnsetin-glu & 67.527 & 335,265 & 493 & $478,331,330,316,315$ & $(50)$ \\
\hline 30 & Gliricidin & 68.182 & 330,272 & 299 & $284,271,256,212,175$ & $(52)$ \\
\hline 31 & Kaempferol methylether & 68.523 & 348,266 & 299 & $285,255,227$ & $(45)$ \\
\hline 32 & 5,7,3'-Trihydroxy-6,4'-dimetoxyflavone & 69.006 & 343,272 & 329 & 314,299 & $(47)$ \\
\hline 33 & 5,7,3'-Trihydroxy-6,4'-dimetoxyflavone & 70.197 & 343,272 & 329 & 314,299 & $(47)$ \\
\hline 34 & 5,7,3'-Trihydroxy-6,4'-dimetoxyflavone & 72.526 & 343,272 & 329 & 314,299 & $(47)$ \\
\hline 35 & 3-Hydroxy-6,7,4'-trimethoxy flavone & 74.865 & 336,247 & 343 & $328,327,313,261$ & $(50)$ \\
\hline 36 & Quercetagetin-tetramethyl ester & 75.648 & 354,272 & 373 & $358,343,328,313$ & $(47)$ \\
\hline 37 & Genkwanin & 77.049 & 335,268 & 283 & 268 & (47) \\
\hline
\end{tabular}

MS/MS, tandem mass spectrometry. [M-H], M; Main structure and H; Hydrogen ion.

previous studies have reported the inhibitory activities of PDJ on macrophage cells for the treatment of inflammation. The present study examined the anti-inflammatory effect of PDJ on LPS-stimulated RAW264.7 cells.

The polyphenolic content in the DJ flower extract was analyzed and identified by HPLC and MS/MS. The results of the MTT assay suggested that PDJ was not cytotoxic to RAW264.7 cells at concentrations $\leq 10 \mu \mathrm{g} / \mathrm{ml}$. Therefore, 2.5 and $5 \mu \mathrm{g} / \mathrm{ml}$ PDJ were used for further experiments to examine the anti-inflammatory effects of PDJ.

Oxidative stress leads to an excessive accumulation of reactive oxygen species, such as $\mathrm{NO}$ and $\mathrm{PGE}_{2}$, in activated 

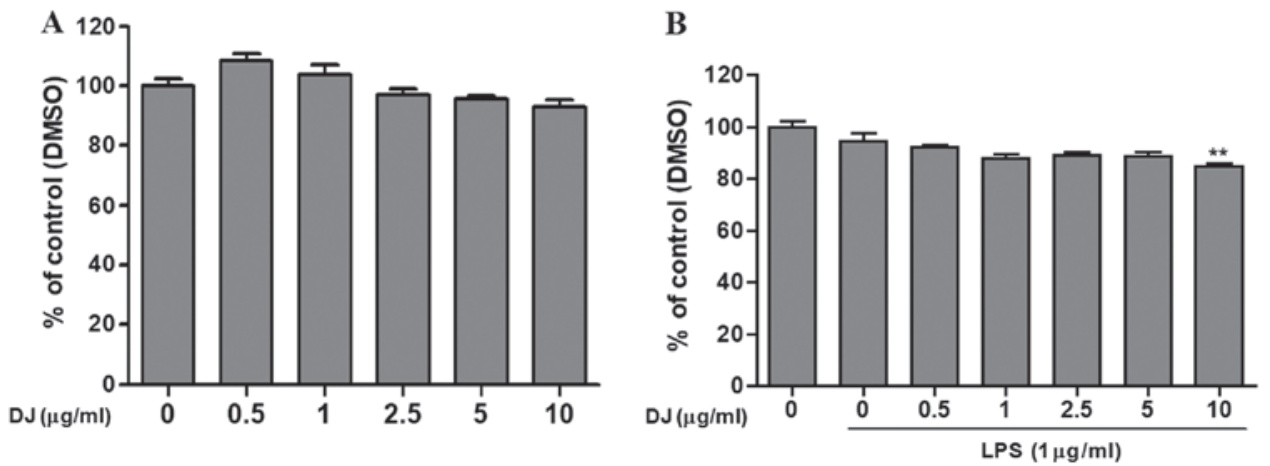

Figure 2. Cytotoxic effect of PDJ on RAW264.7 cells. RAW264.7 cells were pretreated with or without LPS $(1 \mu \mathrm{g} / \mathrm{ml})$ at $37^{\circ} \mathrm{C}$ for $1 \mathrm{~h}$ and then subsequently treated with PDJ $(0,0.5,1,2.5,5$ or $10 \mu \mathrm{g} / \mathrm{ml})$ at $37^{\circ} \mathrm{C}$ for $24 \mathrm{~h}$. (A) Effect of PDJ on non-LPS-induced cell viability in RAW264.7 cells. (B) Effect of PDJ on LPS-induced cell viability in RAW264.7 cells. Data are presented as the mean \pm SEM of three independent experiments. ${ }^{* *} \mathrm{P}<0.005$ vs. LPS-only treated group. PDJ, polyphenolic extract from the Dowijigi flower; LPS, lipopolysaccharide.
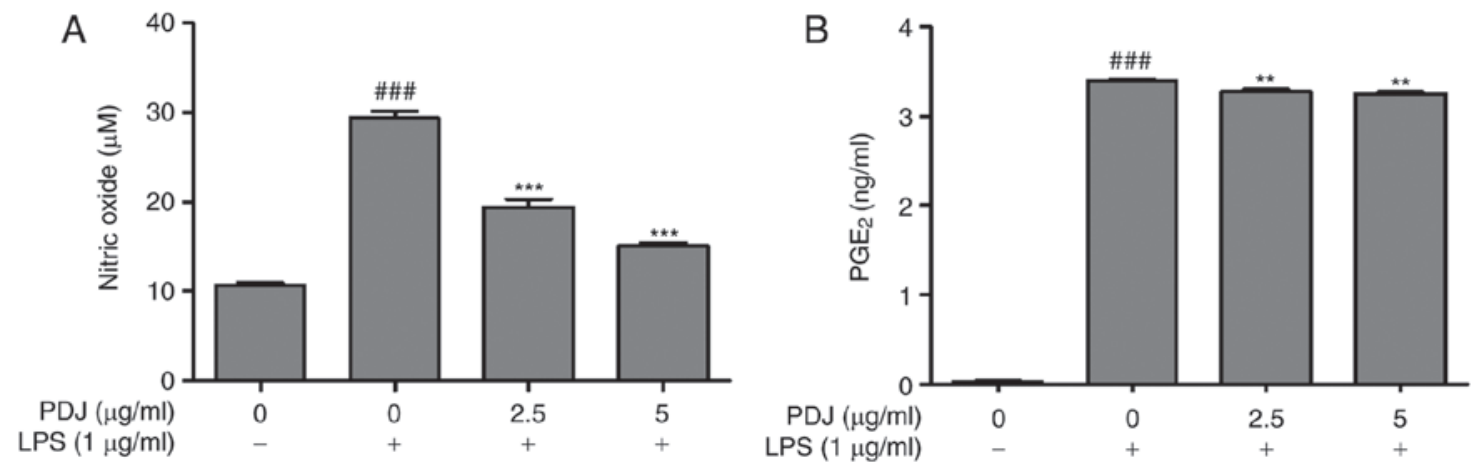

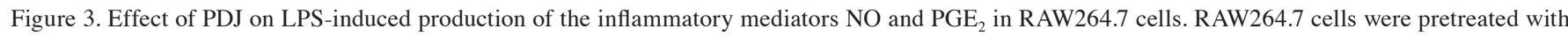
LPS $(1 \mu \mathrm{g} / \mathrm{ml})$ at $37^{\circ} \mathrm{C}$ for $1 \mathrm{~h}$ and then subsequently treated with PDJ $(0,2.5 \mathrm{or} 5 \mu \mathrm{g} / \mathrm{ml})$ for $24 \mathrm{~h}$. (A) NO production. (B) PGE 2 production. Data are presented as the mean \pm SEM of three independent experiments. ${ }^{\# \# \#} \mathrm{P}<0.001$ vs. untreated group; ${ }^{* *} \mathrm{P}<0.005$ vs. LPS-only treated group; ${ }^{* * *} \mathrm{P}<0.001$ vs. LPS-only treated group. PDJ, polyphenolic extract from the Dowijigi flower; LPS, lipopolysaccharide; NO, nitric oxide; $\mathrm{PGE}_{2}$, prostaglandin $\mathrm{E}_{2}$.
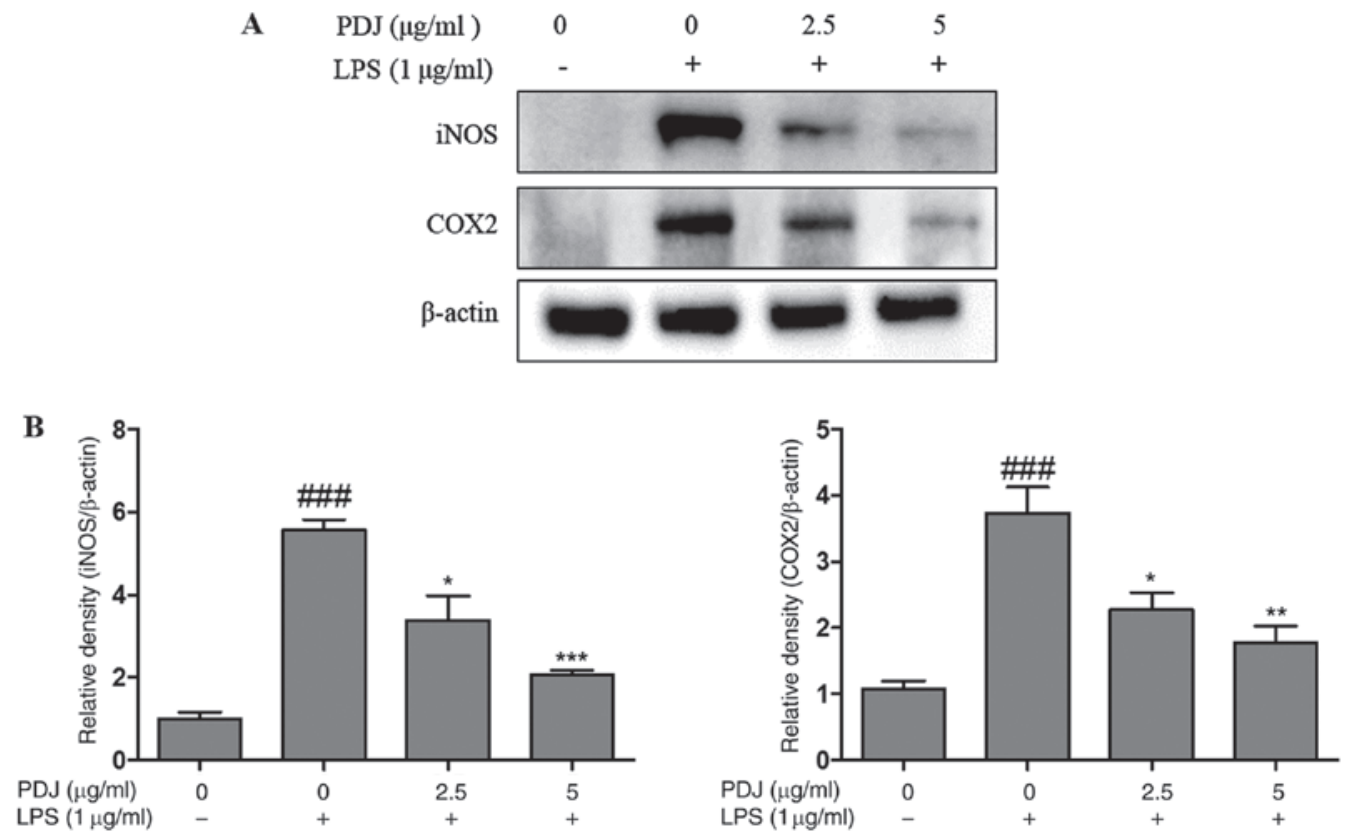

Figure 4. Effect of PDJ on LPS-induced iNOS and COX2 protein expression levels in RAW264.7 cells. RAW264.7 cells were pretreated with LPS ( $1 \mu \mathrm{g} / \mathrm{ml})$ at $37^{\circ} \mathrm{C}$ for $1 \mathrm{~h}$ and then subsequently treated with PDJ $(0,2.5$ or $5 \mu \mathrm{g} / \mathrm{ml})$ at $37^{\circ} \mathrm{C}$ for $24 \mathrm{~h}$. (A) Protein expression levels of iNOS and COX2 in LPS-induced RAW264.7 cells co-treated with PDJ. $\beta$-actin was used as the loading control. (B) Relative expression of iNOS and COX2 bands from western blotting were quantified by densitometry. Data are presented as the mean \pm SEM of three independent experiments. ${ }^{\# \# \#} \mathrm{P}<0.001$ vs. untreated group; ${ }^{*} \mathrm{P}<0.05$ vs. LPS-only treated group; ${ }^{* *} \mathrm{P}<0.01 \mathrm{vs.} \mathrm{LPS-only} \mathrm{treated} \mathrm{group;}{ }^{* * * *} \mathrm{P}<0.001$ vs. LPS-only treated group. PDJ, polyphenolic extract from the Dowijigi flower; LPS, lipopolysaccharide; iNOS, inducible nitric oxide synthase; COX2, cyclooxygenase-2. 

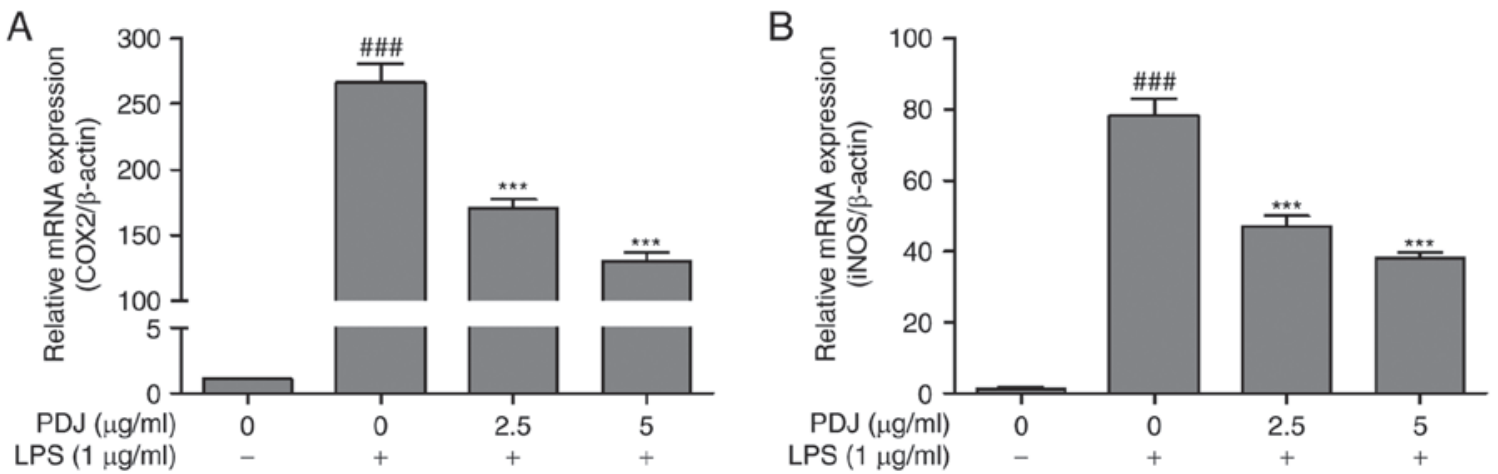

Figure 5. Effect of PDJ on the LPS-induced mRNA expression of COX2 and iNOS in RAW264.7 cells. RAW264.7 cells were pretreated with LPS (1 $\mu \mathrm{g} / \mathrm{ml})$ at $37^{\circ} \mathrm{C}$ for $1 \mathrm{~h}$ and then subsequently treated with PDJ $(0,2.5$ or $5 \mu \mathrm{g} / \mathrm{ml})$ at $37^{\circ} \mathrm{C}$ for $24 \mathrm{~h}$. mRNA expression levels of (A) COX2 and (B) iNOS were measured by reverse transcription-quantitative PCR. Data are presented as the mean \pm SEM of three independent experiments. ${ }^{\# \#} \mathrm{P}<0.001$ vs. untreated group; ${ }^{* * * *} \mathrm{P}<0.001$ vs. LPS-only treated group. PDJ, polyphenolic extract from the Dowijigi flower; LPS, lipopolysaccharide; iNOS, inducible nitric oxide synthase; COX2, cyclooxygenase- 2 .
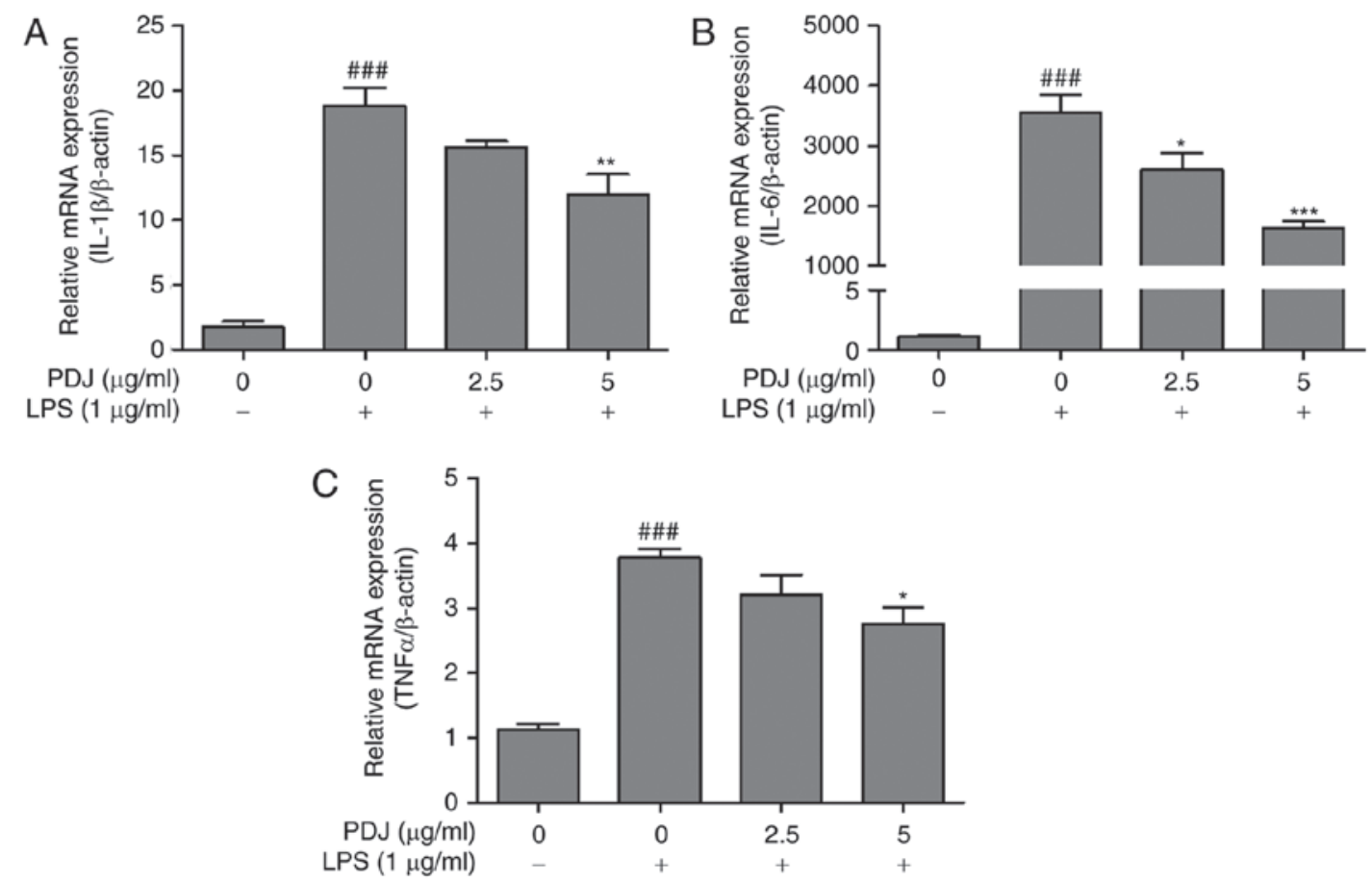

Figure 6. Effect of PDJ on the LPS-induced pro-inflammatory cytokine expression levels in RAW264.7 cells. RAW264.7 cells were pretreated with LPS $(1 \mu \mathrm{g} / \mathrm{ml})$ at $37^{\circ} \mathrm{C}$ for $1 \mathrm{~h}$ and then subsequently treated with PDJ $(0,2.5$ or $5 \mu \mathrm{g} / \mathrm{ml})$ for at $37^{\circ} \mathrm{C} 24 \mathrm{~h} . \mathrm{mRNA}$ expression levels of the pro-inflammatory cytokines (A) IL-1 $\beta$, (B) IL-6 and (C) TNF $\alpha$ were measured by reverse transcription-quantitative PCR. Data are presented as the mean \pm SEM of three independent experiments. ${ }^{\# \# \#} \mathrm{P}<0.001$ vs. untreated group; ${ }^{*} \mathrm{P}<0.05$ vs. LPS-only treated group; ${ }^{* *} \mathrm{P}<0.01$ vs. LPS-only treated group; ${ }^{* * *} \mathrm{P}<0.001$ vs. LPS-only treated group. PDJ, polyphenolic extract from the Dowijigi flower; LPS, lipopolysaccharide; IL, interleukin; TNF, tumor necrosis factor.

macrophages that has been observed in both acute and chronic inflammation in a number of disease conditions, including atherosclerosis, obesity and arthritis (31-33). Inhibition of NO production and $\mathrm{PGE}_{2}$ accumulation modulates the inflammatory response in macrophages, leading to the reduction of swelling and redness at the infection site $(34,35)$. Therefore, the present study investigated $\mathrm{NO}$ and $\mathrm{PGE}_{2}$ production to determine whether PDJ could mediate the inflammatory response in RAW264.7 cells stimulated by LPS and co-treated with PDJ. The results suggested that PDJ effectively inhibited the production of $\mathrm{NO}$ and $\mathrm{PGE}_{2}$.

$\mathrm{NO}$ and $\mathrm{PGE}_{2}$ are produced from $\mathrm{L}$-arginine and arachidonic acid metabolites of the proteins iNOS and COX2 (36). Thus, the mRNA and protein expression levels in LPS-stimulated RAW264.7 cells were analyzed using RT-qPCR and western blotting, respectively. Pretreatment with LPS increased the mRNA and protein expression levels of iNOS and COX2, whereas the expression levels were significantly decreased in a concentration-dependent manner in cells co-treated with PDJ. Collectively, these data suggested that the suppressive effect of $\mathrm{PDJ}$ on $\mathrm{NO}$ and $\mathrm{PGE}_{2}$ production was a result of the inhibition of iNOS and COX2 expression, respectively.

Through synergetic interplay with the pro-inflammatory cytokines TNF $\alpha$, IL- $1 \beta$ and IL-6, iNOS and COX2 aggravate inflammation and the inflammatory response in pathological conditions $(37,38)$. The release of pro-inflammatory cytokines, 

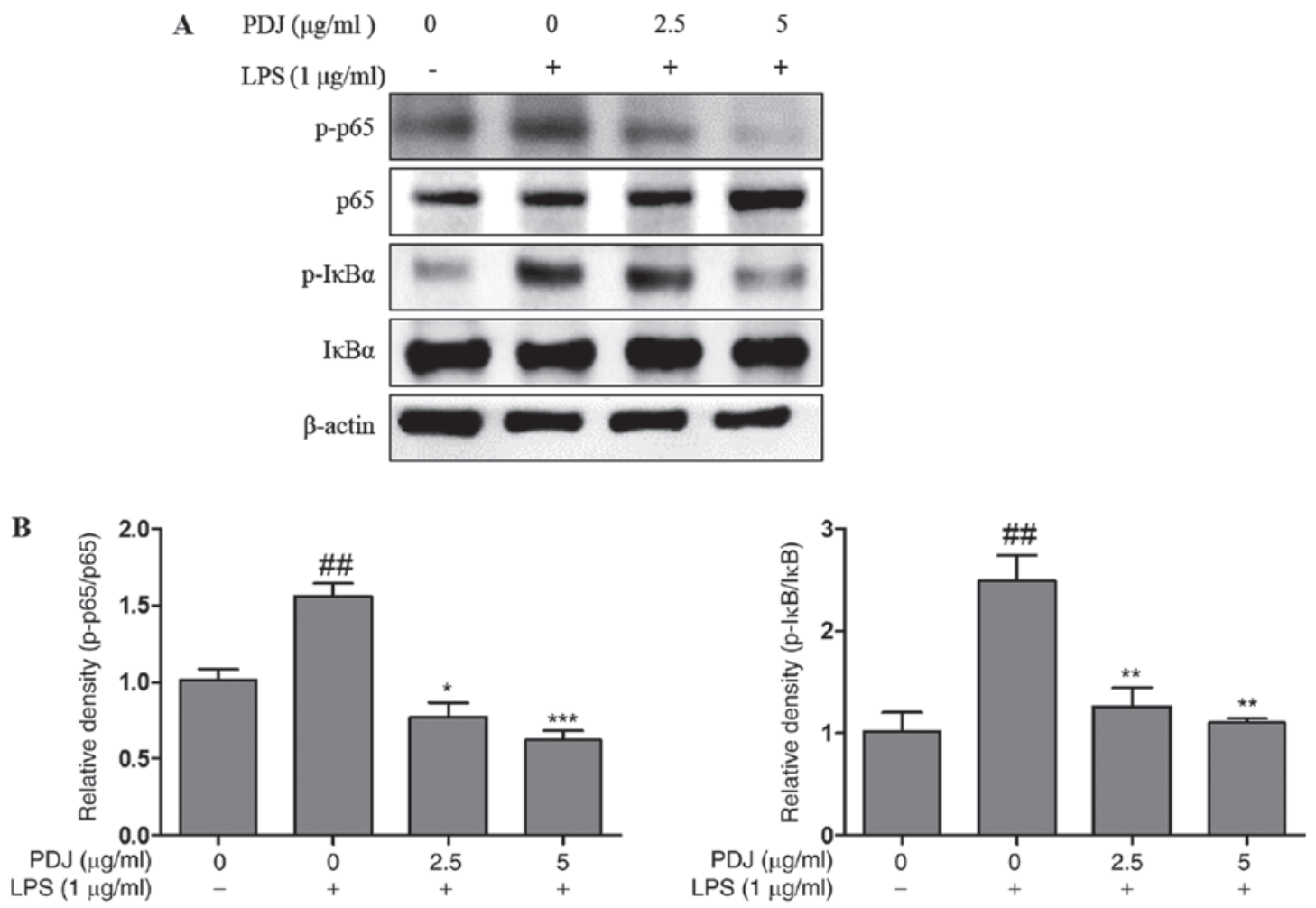

Figure 7. Effect of PDJ on LPS-induced protein expression of p-p65, p65, p-I $\mathrm{KB} \alpha$ and $\mathrm{I \kappa B} \alpha$. RAW264.7 cells were pretreated with $\mathrm{LPS}(1 \mu \mathrm{g} / \mathrm{ml})$ at $37^{\circ} \mathrm{C}$ for $1 \mathrm{~h}$ and then subsequently treated with PDJ $(0,2.5$ or $5 \mu \mathrm{g} / \mathrm{ml})$ for at $37^{\circ} \mathrm{C} 24 \mathrm{~h}$. $\beta$-actin was used as the loading control. (A) Western blot analysis and (B) the relative expression of p-p65/p65 and p-IкB $\alpha / \mathrm{I} \kappa \mathrm{B} \alpha$ ratios quantified by densitometry. Data are presented as the mean \pm SEM of three independent experiments. ${ }^{\# \#} \mathrm{P}<0.01$ vs. untreated group; ${ }^{*} \mathrm{P}<0.05$ vs. LPS-only treated group; ${ }^{* *} \mathrm{P}<0.01$ vs. LPS-only treated group; ${ }^{* * *} \mathrm{P}<0.001$ vs. LPS-only treated group. PDJ, polyphenolic extract from the Dowijigi flower; LPS, lipopolysaccharide; p, phosphorylated; I $\mathrm{K} B \alpha$, inhibitor of $\kappa \mathrm{B} \alpha$.

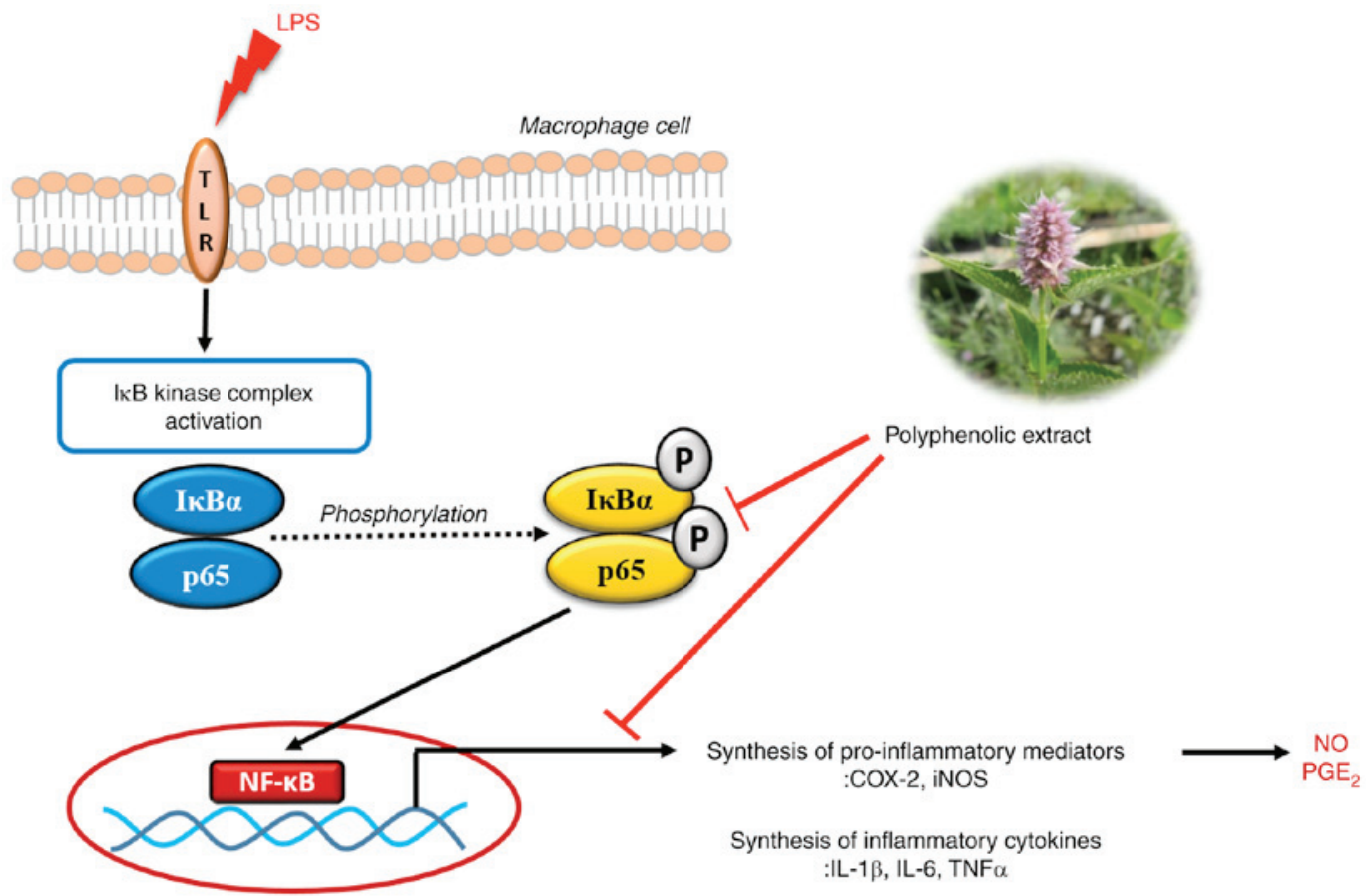

Figure 8. Schematic representation of the NF-kB-mediated inhibition of inflammatory responses by the polyphenolic extract of Dowijigi flower. LPS, lipo-

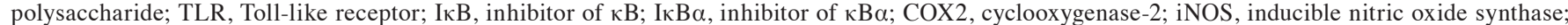
IL, interleukin; TNF, tumor necrosis factor; $\mathrm{NO}$, nitric oxide; $\mathrm{PGE}_{2}$, prostaglandin $\mathrm{E}_{2} ; \mathrm{p}$, phosphorylated.

such as TNF $\alpha$, IL-1 $\beta$ and IL-6, by activated macrophages at the site of infection is an important target for anti-inflammatory therapeutic strategies $(15,19)$. Consistent with the RT-qPCR results, PDJ significantly downregulated the mRNA expression 
levels of TNF $\alpha$, IL-1 $\beta$ and IL-6, suggesting that PDJ exerted anti-inflammatory effects via inhibition of the pro-inflammatory cytokines.

The NF- $\mathrm{B}$ signaling pathway is activated by the phosphorylation, ubiquitination and subsequent proteolytic

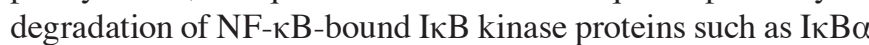
and $\mathrm{p} 65$, which in turn triggers the response of cytokine genes such as TNF $\alpha$, IL-1 $\beta$ and IL- 6 in the nucleus. Moreover, the majority of anti-inflammatory drugs interrupt the inflammatory genes including TNF $\alpha$, IL-1 $\beta$ and IL- 6 via activation of the $\mathrm{NF}-\kappa \mathrm{B}$ signaling pathway $(35,39)$. The expression of the $\mathrm{NF}-\kappa \mathrm{B}$ signaling pathway-related proteins $\mathrm{I} \kappa \mathrm{B} \alpha$ and $\mathrm{p} 65$ in the present study suggested that treatment with PDJ inhibited the phosphorylated forms of $\mathrm{p} 65$ and $\mathrm{I} \kappa \mathrm{B} \alpha$, while the expression levels of the whole form of the proteins remained unchanged. The ratio of $\mathrm{p}-\mathrm{p} 65 / \mathrm{p} 65$ and $\mathrm{p}-\mathrm{I} \kappa \mathrm{B} \alpha / \mathrm{I} \kappa \mathrm{B} \alpha$ were elevated in the LPS-only treated group but were not elevated in the LPS group co-treated with PDJ, indicating that PDJ promoted phosphorylation of the $\mathrm{p} 65$ and $\mathrm{I} \kappa \mathrm{B} \alpha$ proteins via the $\mathrm{NF}-\kappa \mathrm{B}$ signaling pathway to increase immune function in the RAW264.7 cells.

In conclusion, the results of the present study suggested that PDJ exerted anti-inflammatory effects in RAW264.7 cells in vitro by suppressing $\mathrm{NO}$ and $\mathrm{PGE}_{2}$ production, and further displayed the inhibitory effects of PDJ on the inflammatory mediators iNOS and COX 2 and the pro-inflammatory cytokines TNF $\alpha$, IL-1 $\beta$ and IL-6. Furthermore, the anti-inflammatory activity of PDJ might have occurred by direct inhibition of upstream kinases in the activation of the NF- $\kappa \mathrm{B}$ signaling pathway, as summarized in Fig. 8.

\section{Acknowledgements}

Not applicable.

\section{Funding}

The present study was supported partly by TheNational Research Foundation of Korea funded by The Ministry of Science, ICT and Future Planning (grant nos. 2012M3A9B8019303 and 2017R1A2B4003974).

\section{Availability of data and materials}

The datasets used and/or analyzed during the current study are available from the corresponding author on reasonable request.

\section{Authors' contributions}

SMK and PV designed the study, performed the experiments, organized focus group discussions, and collected and analyzed the data. HHK performed the extraction of polyphenols and performed the HPLC analysis. SEH and VVGS performed experiments and prepared the final manuscript. GSK participated in the focus group discussion and revised the study design, the results and the final manuscript for publication. All authors read and approved the final manuscript.

\section{Ethics approval and consent to participate}

Not applicable.

\section{Patient consent for publication}

Not applicable.

\section{Competing interests}

The authors declare that they have no competing interests.

\section{References}

1. Wu C, Zhao W, Zhang X and Chen X: Neocryptotanshinone inhibits lipopolysaccharide-induced inflammation in RAW264.7 macrophages by suppression of NF- $\kappa \mathrm{B}$ and iNOS signaling pathways. Acta Pharm Sin B 5: 323-329, 2015.

2. Jeong SG, Kim S, Kim HG, Kim E, Jeong D, Kim JH, Yang WS Oh J, Sung GH, Hossain MA, et al: Mycetia cauliflora methanol extract exerts anti-inflammatory activity by directly targeting PDK1 in the NF-кB pathway. J Ethnopharmacol 231: 1-9, 2019.

3. de Araújo ERD, Félix-Silva J, Xavier-Santos JB, Fernandes JM, Guerra GCB, de Araújo AA, Araújo DFS, de Santis Ferreira L, da Silva Júnior AA, Fernandes-Pedrosa MF and Zucolotto SM: Local anti-inflammatory activity: Topical formulation containing Kalanchoe brasiliensis and Kalanchoe pinnata leaf aqueous extract. Biomed Pharmacother 113: 108721, 2019.

4. Yang G, Lee K, Lee M, Ham I and Choi HY: Inhibition of lipopolysaccharide-induced nitric oxide and prostaglandin E2 production by chloroform fraction of Cudrania tricuspidata in RAW 264.7 macrophages. BMC Complement Altern Med 12: 250, 2012.

5. Demoruelle MK, Deane KD and Holers VM: When and where does inflammation begin in rheumatoid arthritis? Curr Opin Rheumatol 26: 64-71, 2014.

6. Hotchkiss RS, Moldawer LL, Opal SM, Reinhart K, Turnbull IR and Vincent JL: Sepsis and septic shock. Nat Rev Dis Primers 2: $16045,2016$.

7. Luo G, Cheng BC, Zhao H, Fu XQ, Xie R, Zhang SF, Pan SY and Zhang Y: Schisandra Chinensis Lignans suppresses the production of inflammatory mediators regulated by NF- $\kappa \mathrm{B}, \mathrm{AP}-1$, and IRF3 in lipopolysaccharide-stimulated RAW264.7 Cells. Molecules 23, 2018.

8. Chen L, Deng H, Cui H, Fang J, Zuo Z, Deng J, Li Y, Wang X and Zhao L: Inflammatory responses and inflammation-associated diseases in organs. Oncotarget 9: 7204-7218, 2017.

9. Abdulkhaleq LA, Assi MA, Abdullah R, Zamri-Saad M, Taufiq-Yap YH and Hezmee MNM: The crucial roles of inflammatory mediators in inflammation: A review. Vet World 11: 627-635, 2018.

10. Meng F and Lowell CA: Lipopolysaccharide (LPS)-induced macrophage activation and signal transduction in the absence of Src-family kinases Hck, Fgr, and Lyn. J Exp Med 185: 1661-1670, 1997.

11. Hutchins AP, Takahashi Y and Miranda-Saavedra D: Genomic analysis of LPS-stimulated myeloid cells identifies a common pro-inflammatory response but divergent IL-10 anti-inflammatory responses. Sci Rep 5: 9100, 2015.

12. Cecilia OM, José Alberto CG, José NP, Ernesto Germán CM, Ana Karen LC, Luis Miguel RP, Ricardo Raúl RR and Adolfo Daniel RC: Oxidative stress as the main target in diabetic retinopathy pathophysiology. J Diabetes Res 2019: 8562408, 2019.

13. Zuo L, Prather ER, Stetskiv M, Garrison DE, Meade JR, Peace TI and Zhou T: Inflammaging and oxidative stress in human diseases: From molecular mechanisms to novel treatments. Int J Mol Sci 20, 2019.

14. Mayouf N, Charef N, Saoudi S, Baghiani A, Khennouf S and Arrar L: Antioxidant and anti-inflammatory effect of Asphodelus microcarpus methanolic extracts. J Ethnopharmacol 239: 111914, 2019.

15. Han JM, Lee EK, Gong SY, Sohng JK, Kang YJ and Jung HJ: Sparassis crispa exerts anti-inflammatory activity via suppression of TLR-mediated NF- $\kappa \mathrm{B}$ and MAPK signaling pathways in LPS-induced RAW264.7 macrophage cells. J Ethnopharmacol 231: 10-18, 2019.

16. Shah M, Ullah MA, Drouet S, Younas M, Tungmunnithum D, Giglioli-Guivarc'h N, Hano C and Abbasi BH: Interactive effects of light and melatonin on biosynthesis of silymarin and anti-inflammatory potential in callus cultures of Silybum marianum (L.) Gaertn. Molecules 24: 1207, 2019.

17. Lawrence T: The nuclear factor NF-kappaB pathway in inflammation. Cold Spring Harb Perspect Biol 1: a001651, 2009. 
18. Song C, Hong YH, Park JG, Kim HG, Jeong D, Oh J, Sung GH, Hossain MA, Taamalli A, Kim JH, et al: Suppression of Src and Syk in the NF- $\kappa \mathrm{B}$ signaling pathway by Olea europaea methanol extract is leading to its anti-inflammatory effects. J Ethnopharmacol 235: 38-46, 2019.

19. Han SY, Yi YS, Jeong SG, Hong YH, Choi KJ, Hossain MA, Hwang H, Rho HS, Lee J, Kim JH and Cho JY: Ethanol extract of Lilium bulbs plays an anti-inflammatory role by targeting the IKK[Formula: see text]/[Formula: see text]-mediated NF-[Formula: see text]B pathway in macrophages. Am J Chin Med 46: 1281-1296, 2018

20. Han B, Dai Y, Wu H, Zhang Y, Wan L, Zhao J, Liu Y, Xu S and Zhou L: Cimifugin inhibits inflammatory responses of RAW264.7 cells induced by lipopolysaccharide. Med Sci Monit 25: 409-417, 2019.

21. Abad MJ, Bedoya LM, Apaza L and Bermejo P: The Artemisia L. genus: A review of bioactive essential oils. Molecules 17: 2542-2566, 2012.

22. Lee J, Narayan VP, Hong EY, Whang WK and Park T: Artemisia iwayomogi extract attenuates high-fat diet-induced hypertriglyceridemia in mice: Potential involvement of the adiponectin-AMPK pathway and very low density lipoprotein assembly in the liver. Int J Mol Sci 18, 2017.

23. Lee YK, Hong EY and Whang WK: Inhibitory effect of chemical constituents isolated from Artemisia iwayomogi on polyol pathway and simultaneous quantification of major bioactive compounds. Biomed Res Int 2017: 7375615, 2017.

24. Sandhiutami NM, Moordiani M, Laksmitawati DR, Fauziah N, Maesaroh $\mathrm{M}$ and Widowati W: In vitro assesment of anti-inflammatory activities of coumarin and Indonesian cassia extract in RAW264.7 murine macrophage cell line. Iran J Basic Med Sci 20: 99-106, 2017.

25. Erbel C, Rupp G, Helmes CM, Tyka M, Linden F, Doesch AO, Katus HA and Gleissner CA: An in vitro model to study heterogeneity of human macrophage differentiation and polarization. J Vis Exp: e50332, 2013.

26. Livak KJ and Schmittgen TD: Analysis of relative gene expression data using real-time quantitative PCR and the 2(-Delta Delta C(T)) method. Methods 25: 402-408, 2001

27. Pan SY, Zhou SF, Gao SH, Yu ZL, Zhang SF, Tang MK, Sun JN Ma DL, Han YF, Fong WF and Ko KM: New perspectives on how to discover drugs from herbal medicines: CAM's outstanding contribution to modern therapeutics. Evid Based Complement Alternat Med 2013: 627375, 2013.

28. Maione F, Russo R, Khan H and Mascolo N: Medicinal plants with anti-inflammatory activities. Nat Prod Res 30: 1343-1352, 2016

29. Yu HH, Kim YH, Kil BS, Kim KJ, Jeong SI and You YO Chemical composition and antibacterial activity of essential oil of Artemisia iwayomogi. Planta Med 69: 1159-1162, 2003.

30. Park WS, Son YK, Ko EA, Choi SW, Kim N, Choi TH, Youn HJ, Jo SH, Hong DH and Han J: A carbohydrate fraction, AIP1, from Artemisia iwayomogi reduces the action potential duration by activation of rapidly activating delayed rectifier $\mathrm{K}$ channels in rabbit ventricular myocytes. Korean J Physiol Pharmacol 14: $119-125,2010$

31. Abramson SB: Nitric oxide in inflammation and pain associated with osteoarthritis. Arthritis Res Ther 10 (Suppl 2): S2, 2008.

32. Li T, Liu B, Guan H, Mao W, Wang L, Zhang C, Hai L, Liu K and Cao J: PGE2 increases inflammatory damage in Escherichia coli-infected bovine endometrial tissue in vitro via the EP4-PKA signaling pathway. Biol Reprod 100: 175-186, 2019.

33. Ezzat SM, Raslan M, Salama MM, Menze ET and El Hawary SS: In vivo anti-inflammatory activity and UPLC-MS/MS profiling of the peels and pulps of Cucumis melo var. cantalupensis and Cucumis melo var. reticulatus. J Ethnopharmacol 237: 245-254, 2019.

34. Park SB, Park GH, Kim HN, Son HJ, Song HM, Kim HS, Jeong HJ and Jeong JB: Anti-inflammatory effect of the extracts from the branch of Taxillus yadoriki being parasitic in Neolitsea sericea in LPS-stimulated RAW264.7 cells. Biomed Pharmacother 104: 1-7, 2018.

35. Hong GE, Kim JA, Nagappan A, Yumnam S, Lee HJ, Kim EH Lee WS, Shin SC, Park HS and Kim GS: Flavonoids identified from Korean Scutellaria baicalensis georgi inhibit inflammatory signaling by suppressing activation of NF- $\mathrm{KB}$ and MAPK in RAW 264.7 cells. Evid Based Complement Alternat Med 2013: 912031, 2013

36. Herencia F, Ferrándiz ML, Ubeda A, Guillén I, Dominguez JN, Charris JE, Lobo GM and Alcaraz MJ: Novel anti-inflammatory chalcone derivatives inhibit the induction of nitric oxide synthase and cyclooxygenase-2 in mouse peritoneal macrophages. FEBS Lett 453: 129-134, 1999 .
37. Muniandy K, Gothai S, Badran KMH, Suresh Kumar S, Esa NM and Arulselvan P: Suppression of proinflammatory cytokines and mediators in LPS-induced RAW 264.7 macrophages by stem extract of Alternanthera sessilis via the inhibition of the NF- $\kappa \mathrm{B}$ pathway. J Immunol Res 2018: 3430684, 2018.

38. Wojdasiewicz P, Poniatowski ŁA and Szukiewicz D: The role of inflammatory and anti-inflammatory cytokines in the pathogenesis of osteoarthritis. Mediators Inflamm 2014: 561459, 2014

39. Tzeng HE, Tsai CH, Ho TY, Hsieh CT, Chou SC, Lee YJ, Tsay GJ, Huang PH and Wu YY: Radix Paeoniae Rubra stimulates osteoclast differentiation by activation of the NF- $\kappa \mathrm{B}$ and mitogen-activated protein kinase pathways. BMC Complement Altern Med 18: 132, 2018.

40. Fernandes A, Sousa A, Mateus N, Cabral M and de Freitas V: Analysis of phenolic compounds in cork from Quercus suber L. by HPLC-DAD/ESI-MS. Food Chem 125: 1398-1405, 2011.

41. Del Rio D, Stewart AJ, Mullen W, Burns J, Lean ME, Brighenti F and Crozier A: HPLC-MSn analysis of phenolic compounds and purine alkaloids in green and black tea. J Agric Food Chem 52: 2807-2815, 2004

42. Prasain JK, Peng N, Dai Y, Moore R, Arabshahi A, Wilson L, Barnes S, Michael Wyss J, Kim H and Watts RL: Liquid chromatography tandem mass spectrometry identification of proanthocyanidins in rat plasma after oral administration of grape seed extract. Phytomedicine 16: 233-243, 2009.

43. Gardana C, Scaglianti M, Pietta P and Simonetti P: Analysis of the polyphenolic fraction of propolis from different sources by liquid chromatography-tandem mass spectrometry. J Pharm Biomed Anal 45: 390-399, 2007.

44. Han B, Xin Z, Ma S, Liu W, Zhang B, Ran L, Yi L and Ren D: Comprehensive characterization and identification of antioxidants in Folium Artemisiae Argyi using high-resolution tandem mass spectrometry. J Chromatogr B Analyt Technol Biomed Life Sci 1063: 84-92, 2017.

45. Barros L, Dueñas M, Carvalho AM, Ferreira IC and Santos-Buelga C: Characterization of phenolic compounds in flowers of wild medicinal plants from Northeastern Portugal. Food Chem Toxicol 50: 1576-1582, 2012.

46. Li F, Zhang YB, Wei X, Song CH, Qiao MQ and Zhang HY: Metabolic profiling of Shu-Yu capsule in rat serum based on metabolic fingerprinting analysis using HPLC-ESI-MSn. Mol Med Rep 13: 4191-4204, 2016.

47. Olennikov DN, Chirikova NK, Kashchenko NI, Nikolaev VM, Kim SW and Vennos C: Bioactive phenolics of the genus Artemisia (Asteraceae): HPLC-DAD-ESI-TQ-MS/MS profile of the Siberian species and their inhibitory potential against $\alpha$-amylase and $\alpha$-glucosidase. Front Pharmacol 9: 756, 2018.

48. Pati S, Losito I, Gambacorta G, La Notte E, Palmisano F and Zambonin PG: Simultaneous separation and identification of oligomeric procyanidins and anthocyanin-derived pigments in raw red wine by HPLC-UV-ESI-MSn. J Mass Spectrom 41: 861-871, 2006.

49. Schütz K, Kammerer DR, Carle R and Schieber A: Characterization of phenolic acids and flavonoids in dandelion (Taraxacum officinale WEB. ex WIGG.) root and herb by high-performance liquid chromatography/electrospray ionization mass spectrometry. Rapid Commun Mass Spectrom 19: 179-186, 2005.

50. Han J, Ye M, Qiao X, Xu M, Wang BR and Guo DA: Characterization of phenolic compounds in the Chinese herbal drug Artemisia annua by liquid chromatography coupled to electrospray ionization mass spectrometry. J Pharm Biomed Anal 47: 516-525, 2008

51. Orčić D, Francišković M, Bekvalac K, Svirčev E, Beara I, Lesjak M and Mimica-Dukić N: Quantitative determination of plant phenolics in Urtica dioica extracts by high-performance liquid chromatography coupled with tandem mass spectrometric detection. Food Chem 143: 48-53, 2014

52. Ye M, Yang WZ, Liu KD, Qiao X, Li BJ, Cheng J, Feng J, Guo DA and Zhao YY: Characterization of flavonoids in Millettia nitida var. hirsutissima by HPLC/DAD/ESI-MS ${ }^{\mathrm{n}}$. J Pharm Anal 2: 35-42, 2012.

This work is licensed under a Creative Commons Attribution-NonCommercial-NoDerivatives 4.0 International (CC BY-NC-ND 4.0) License. 